DOI 10.35220/2078-8916-2020-35-2-

УДК 616-089.23.004-312-71:001.5.008.5

С.В. Рачинський, С.А. Шнайдер, д.м.н., О.В. Лабунець, к.м.н., Т.В Дієва, д.м.н., В.А. Лабунець, д.м.н., *О.Ф. Дзигал, д. мед. н.

Державна установа «Інститут стоматології та щелепно-лицевої хірургії Національної академії медичних наук України»

*Одеський національний медичний університет

\section{ПОТРЕБА ТА ЗАБЕЗПЕЧЕНІСТЬ МОЛОДИХ ОСІБ ПРИЗОВНОГО ВІКУ У СТОМАТОЛОГІЧНІЙ ОРТОПЕДИЧНІЙ ДОПОМОЗІ}

Проведені стоматологічні огляди 294 осіб призовного віку чоловічої статі, з яких міських - 185 і сільських 109. Встановлена висока розповсюдженість стоматологічної ортопедичної захворюваності, яка склала серед міського населення 275,5 $i$ серед сільського 522,9 осіб на 1000 населення даної вікової групи.

Визначено значний об'єм необхіднӧ ортопедичної допомоги даній категорії населення $i$ вкрай низький з наданого протезування. При ицьому рівень задоволеності по основним видам зубних протезів складає, по одиночним коронкам 6,2 \% серед міського $і$ 3,3\% серед сільського, при практично повній відсутності виготовлення мостоподібних протезів $і$ штифтових конструкцій. Обгрунтована необхідність реформування організації надання ортопедичної допомоги призовникам та ї̈ удосконалення.

Ключові слова: чоловіки призовного віку, ортопедична захворюваність, потреба, забезпеченість, зубні протези, міське, сільське населення.

\section{С.В Рачинский, С. А. Шнайдер, О.В. Лабунеи,} Т.В. Диева, В.А. Лабунеи, *О.Ф. Дзигал

Государственное учреждение «Институт стоматологии и челюстно-лицевой хирургии Национальной академии медицинских наук Украины»

*Одеський національний медичний університет

\section{НУЖДАЕМОСТЬ И ОБЕСПЕЧЕННОСТЬ МОЛОДЫХ ЛИЦ ПРИЗЫВНОГО ВОЗРАСТА В СТОМАТОЛОГИЧЕСКОЙ ОРТОПЕДИЧЕСКОЙ ПОМОЩИ}

Проведень стоматологические осмотры 294 лич призывного возраста мужского пола, из которых городских - 185 и сельских - 109. Установлена высокая распространенность стоматологической ортопедической заболеваемости, которая составила среди городского населения 275,5 и среди сельского - 522,9 лии на 1000 населения данной возрастной группьл. Onределён значительньй объем необходимой ортопедической помощи данной категории населения и крайне низкий уровень оказанного протезирования. При этом уровень удовлетворённости по основным видам зубных протезов составляет, по одиночным коронкам 6,2\% среди городского и 3,3\% среди сельского, при практически полном отсутствии изготовления мостовидных зубных протезов и штифтовых конструкциий. Обоснована необходимость реформирования организации оказания ортопедической помощи и её усовериенствования.

Ключевые слова: мужчины призывного возраста, ортопедическая заболеваемость, обеспеченность, нуждаемость, зубные протезы, городское, сельское население.

\section{S.V. Rachinsky, S.A. Schneider, O.V. Labunets, T.V. Dieva, V. A. Labunets, *A. F. Dzygal}

State Establishment «The Institute of Stomatology and Maxillo-Facial Surgery

National Academy of Medical Science of Ukraine»

*Odessa National Medical University

\section{NEED AND SECURITY OF YOUNG PEOPLE OF MILITARY AGE IN DENTAL ORTHOPEDIC CARE}

\section{ABSTRACT}

Dental examinations were conducted for 294 men of draft age, of which urban - 185 and rural - 109. A high prevalence of dental orthopedic morbidity was established, which amounted to 275.5 among the urban population and 522.9 people among the rural population per 1000 population of this age group. A significant amount of necessary orthopedic care for this category of the population and extremely low rendered prosthetics were determined. At the same time, the level of satisfaction with the main types of dentures is $6.2 \%$ for urban crowns and $3.3 \%$ for rural crowns, with almost no manufacturing of bridge prostheses and pin designs. The necessity of reforming the organization of orthopedic care and its improvements is substantiated.

Key words: men of draft age, orthopedic incidence, wealth, poverty, dentures, urban, rural population.

На сьогодення існує достатня кількість наукових досліджень 3 питань загальної та ортопедичної стоматологічної захворюваності у молодих осіб нашої країни [1-9]. Приділяється увага їі стану i серед військовослужбовців рядового складу, особливо в останні роки [10-14]. Разом 3 тим спрямованих науково-дослідних робіт з питань визначення величини потреби, ступеня забезпеченості та рівня надання спеціалізованої ортопедичної допомоги чоловікам призовного віку у нашій державі, на жаль, практично немає. Зважаючи на наведене вище, метою даної науково-прикладної роботи саме і стало визначення стоматологічної ортопедичної захворюваності у даної категорії населення у західному регіоні України та, на їх підставі, встановлення оптима- 
льного об'єму потреби в ортопедичній допомозі та ступеня їх задоволеності в основних видах зубних протезів.

Матеріали і методи дослідження. Об'єктом дослідження служила стоматологічна ортопедична захворюваність та стан надання ортопедичної допомоги мешканцям чоловічої статі призовного віку до 20 років Івано-Франківської області, як одному із найбільш характерних медіогеографічних регіонів нашої країни.

Матеріалами дослідження були дані епідеміологічних стоматологічних оглядів даної категоpiï населення, структура й об'єм виготовлених основних видів зубних протезів і які потрібно ще виготовити для повноцінної ортопедичної їх реабілітації.

У процесі стоматологічних оглядів було проведено поглиблене клінічне обстеження 294 чоловіків призовного віку до 20 років, з яких міське населення склало 185 і сільське 109 осіб, стоматологічний статус яких фіксувався в спеціальній "Карті обстеження стоматологічного ортопедичного хворого”, розробленій в ДУ «Інститут стоматології та щелепно-лицьової хірургії НАМН України», з віддзеркаленням також тера- певтичної, хірургічної, ортодонтичної та пародонтологічної патології. Окрім цього реєструвались також основні виготовлені види зубних протезів та які потребують ще додаткового виготовлення згідно розробленого спеціального шифратора. Усі отримані матеріали піддавались статистичній обробці з обчисленням середньої арифметичної величини, що достатньо при проведенні подібних епідеміологічних досліджень з урахуванням методичних рекомендацій Комітету Експертів ВО3 [15, 16], згідно яких у одній віковій групі повинно бути не менше 30 обстежених для отримання достовірних даних. При цьому, усі розрахунки проводились 3 обчисленням середньостатистичної величини на 1000 осіб відповідної вікової групи, як на то потребує санітарна статистика.

Результати дослідження та їх обговорен$\boldsymbol{\mu} \boldsymbol{я . ~ П е р ш ~ н і ж ~ н а д а т и ~ м а т е р і а л и ~ і ~ х а р а к т е р и з у в а т и ~}$ стан, рівень надання і ступінь задоволеності молодих осіб призовного віку Івано-Франківської області і повноцінного його сприйняття та порівняльного аналізу, у табл.1 наведені показники стоматологічної ортопедичної захворюваності у даної категорії населення.

Таблиця 1

Стоматологічна ортопедична захворюваність чоловіків призовного віку ІваноФранківської області, на 1000 осіб

\begin{tabular}{|c|c|c|c|c|c|c|c|}
\hline \multirow[t]{2}{*}{ Населення } & \multirow[t]{2}{*}{$\begin{array}{c}\text { Кількість осіб, } \\
\text { які підлягають } \\
\text { протезуванню }\end{array}$} & \multirow[t]{2}{*}{$\begin{array}{c}\text { Кількість зубів, } \\
\text { які підлягають } \\
\text { протезуванню }\end{array}$} & \multirow{2}{*}{$\begin{array}{c}\text { Кількість дефек- } \\
\text { тів зубних рядів, } \\
\text { які підлягають } \\
\text { протезуванню }\end{array}$} & \multicolumn{2}{|c|}{$\begin{array}{c}\text { Кількість видалених } \\
\text { зубів }\end{array}$} & \multicolumn{2}{|c|}{$\begin{array}{c}\text { Кількість зубів і дефе- } \\
\text { ктів зубних рядів, які } \\
\text { підлягають ортопедич- } \\
\text { ному лікуванню }\end{array}$} \\
\hline & & & & всього & $\begin{array}{l}\text { на 1-го об- } \\
\text { стеженого }\end{array}$ & всього & $\begin{array}{l}\text { на 1-го об- } \\
\text { стеженого }\end{array}$ \\
\hline Міське & 275,7 & 578,4 & 189,2 & 210,8 & 0,21 & 787,6 & 0,77 \\
\hline Сільське & 522,9 & 1302,8 & 596,3 & 651,4 & 0,65 & 1899,1 & 1,90 \\
\hline
\end{tabular}

Так, згідно представленими у табл.1 матеріалам, кількість осіб, які підлягають ортопедичному лікуванню становить серед міських мешканців 275,5 і 522,9 осіб серед сільських, відповідно, на 1000 осіб даної вікової групи і статті. При цьому, кількість зубів зі зруйнованою коронковою частиною твердих тканин, що підлягають протезуванню серед міського населення складає
578,4 і 1302,8 серед сільського. Кількість же дефектів зубних рядів, які також потребують протезування наступна - 189,2 та 596,3 відповідно серед міського і сільського населення на 1000 осіб. Назагал, кількість зубів і дефектів зубних рядів серед міських мешканців даного віку становить 787,6 і 1899,1 серед сільських.

Таблиця 2

Кількість основних видів зубних протезів, які підлягають виготовленню серед чоловіків призовного віку Івано-Франківської області, на 1000 осіб

\begin{tabular}{|c|c|c|c|c|c|}
\hline \multirow{2}{*}{ Населення } & \multicolumn{4}{|c|}{ Види зубних протезів } \\
\cline { 2 - 6 } & одиночні коронки & $\begin{array}{c}\text { мостоподібні про- } \\
\text { тези }\end{array}$ & штифтові зуби & $\begin{array}{c}\text { бюгельні } \\
\text { протези }\end{array}$ & $\begin{array}{c}\text { знімні часткові } \\
\text { пластинкові протези }\end{array}$ \\
\hline Міське & 2098,0 & 189,2 & 102,7 & - & - \\
\hline Сільське & 2491,0 & 588,8 & 271,0 & - & - \\
\hline
\end{tabular}


Таблиця 3

Кількість виготовлених основних видів зубних протезів серед чоловіків призовного віку ІваноФранківської області, на 1000 осіб

\begin{tabular}{|c|c|c|c|c|c|c|}
\hline \multirow[b]{2}{*}{ Населення } & \multicolumn{6}{|c|}{ Види зубних протезів } \\
\hline & $\begin{array}{c}\text { одиночні ко- } \\
\text { ронки }\end{array}$ & $\begin{array}{c}\text { мостоподібні } \\
\text { протези }\end{array}$ & штифтові зуби & $\begin{array}{c}\text { бюгельні } \\
\text { протези }\end{array}$ & $\begin{array}{c}\text { знімні часткові } \\
\text { пластинкові про- } \\
\text { тези }\end{array}$ & імплантати \\
\hline Міське & 129,7 & - & - & - & - & 21,6 \\
\hline Сільське & 82,6 & - & - & - & - & - \\
\hline
\end{tabular}

Таблиця 4

Рівень задоволеності чоловіків призовного віку Івано-Франківської області в основних видах зубних протезів

\begin{tabular}{|c|c|c|c|c|c|c|c|c|c|}
\hline \multirow{2}{*}{$\begin{array}{c}\text { Насе- } \\
\text { лення }\end{array}$} & \multicolumn{9}{|c|}{ Види зубних протезів } \\
\cline { 2 - 10 } & $\begin{array}{c}\text { потребу- } \\
\text { ють виго- } \\
\text { товлення }\end{array}$ & $\begin{array}{c}\text { вигото- } \\
\text { влені }\end{array}$ & $\begin{array}{c}\text { забезпе- } \\
\text { ченісь у } \%\end{array}$ & $\begin{array}{c}\text { потребу- } \\
\text { ють виго- } \\
\text { товлення }\end{array}$ & $\begin{array}{c}\text { виготов- } \\
\text { лені }\end{array}$ & $\begin{array}{c}\text { забезпе- } \\
\text { ченісь у \% }\end{array}$ & $\begin{array}{c}\text { потребу- } \\
\text { ють виго- } \\
\text { товлення }\end{array}$ & $\begin{array}{c}\text { виготов- } \\
\text { лені }\end{array}$ & $\begin{array}{c}\text { забезпе- } \\
\text { ченісь у } \\
\%\end{array}$ \\
\hline Міське & 2098,0 & 129,7 & 6,2 & 189,2 & 0 & 0 & 102,7 & 0 & 0 \\
\hline $\begin{array}{c}\text { Сіль- } \\
\text { ське }\end{array}$ & 2491,0 & 82,6 & 3,3 & 588,8 & 0 & 0 & 271,0 & 0 & 0 \\
\hline
\end{tabular}

Наведені показники вельми показово свідчать, як для даного віку, про достатньо значну розповсюдженість і об'єм ортопедичної патології, які потребують протезування. Саме на фоні даних показників стає вкрай зрозумілим фактичний рівень надання ортопедичної допомоги, безпосередній стан якої віддзеркалено у таблицях 2 , 3,4 .

Так, згідно представлених у табл. 2 даних, кількість одиночних коронок, які підлягають виготовленню серед міського населення становить 2098,0 на 1000 осіб даної вікової групи, а сільського - 2491,0. Мостоподібних протезів відповідно 189,2 і 588,8, а штифтових конструкцію також відповідно 102,7 і 271,0 серед міських і сільських мешканців.

Щоб встановити ступінь задоволеності даних осіб у відповідних видах ортопедичної допомоги у табл. 2 наведені показники об'єма виготовлених зубних протезів, які становлять по одиночним коронкам 129,7 і 82,6 серед міського i сільського населення відповідно. Що стосується виготовлених мостоподібних протезів і штифтових зубів, як за нашими даними, то вони практично серед даної категорії молодих осіб не виготовляються і це визиває гостре занепокоєння, особливо відносно мостоподібних протезів, несвоєчасне виготовлення яких, на думку переважної більшості дослідників, приводить, особливо у молодому віці, до появи і стрімкому розвитку вторинних зубощелепних аномалій і деформацій, які значно утруднюють відповідне подальше протезування, не кажучи вже про різке збільшення вимушеної передпротезної підготовки та iii фінансової складової, особливо у теперішніх умовах економічного стану нашої країни.

Що стосується імплантатів, то ми їх умисно не розглядали цього питання, використання яких у цьому віці, при наявності повних їх клінічних показах, залежить нажаль у повній мірі від добробуту населення і $\epsilon$ не самим визначальним показником у загальному об'ємі ортопедичної допомоги.

Зважаючи на це, у табл.3 наведено рівень задоволеності чоловіків призовного віку в основних видах зубних протезів. Згідно представлених даних ступінь їх задоволеності в ортопедичному лікуванні вкрай низька, якщо не сказати ніяка. По одиночним коронкам складає всього 6,2 \% серед міського і 3,3 \% - сільського населення від загальної потреби. По мостоподібним протезам і штифтовим зубам практично нульова. Аналізуючи наведені показники слід констатувати про вкрай незадовільний стан надання ортопедичної допомоги даній категорії населення країни.

Більш того на наше переконання, вже у недалекому майбутньому, приймаючи до уваги вельми низький рівень задоволеності їх в одиночних коронках і досить значний рівень розповсюдженості руйнованих зубів, які потребують ортопедичного лікування, при відсутності надання їм дієвої спеціалізованої допомоги, різко зросте кількість видалених зубів, а значить і об'єм мостоподібних протезів та їх вторинних ускладнень.

Висновки. 1. Спостерігається достатньо висока розповсюдженість стоматологічної ортопедичної захворюваності серед чоловіків призовного віку, яка становить 522,9 серед сільського 275,5 серед міського населення на 1000 осіб даної вікової групи і статі. При цьому серед сільсь- 
ких мешканців вона у 1,9 разів вища ніж у міських, а об'єм ортопедичної допомоги у 2,3 рази.

2. Встановлено, зважаючи на молодий вік обстежених, вельми значний необхідний об'єм ортопедичної допомоги даній категорії населення, який складає по одиночним коронкам 2098,0, мостоподібним протезам 189,2 і штифтовим зубам 102,7 серед міського населення i, відповідно 2491,0, 588,8 і 271,0 серед сільського населення на 1000 осіб.

3. Визначено вкрай незначний об'єм виготовлених зубних протезів як серед міських, так i сільських мешканців призовного віку і стосується це тільки одиночних коронок, які складають відповідно 129,7 і 82,6 одиниць, при практично повній відсутності виготовлення мостоподібних протезів і штифтових зубів, як таких.

4. Доведено про незадовільний стан надання стоматологічної ортопедичної допомоги даній категорії населення країни та нагальну необхідність реформування системи організації ії надання.

\section{Список літератури}

1. Мунтян Л.М. Частота виникнення, поширеність вторинних часткових адентій та зубощелепних деформацій у осіб молодого віку/ Л.М. Мунтян, А.М. Юр// Український стоматологічний альманах. - 2010. - №5. - с.25-26.

2. Ожоган 3.P. Особливості клінічної картини дефектів зубних рядів у осіб молодого віку/ 3.Р. Ожоган, Л.П. Вдовенко// Дентальні технології. - 2006. - №3-6 (28-31). с.19-21.

3. Максєв В.Ф. Частота дефектів зубів та зубних рядів у пацієнтів 13-17 років залежно від віку/ В.Ф. Макєєв, Г.В. Мартінек// Український стоматологічний альманах. 2012. - №4. - c.106-110.

4. Лабунец В.А. Повозрастной характер распространенности дефектов зубных рядов и дефектов коронковой части зубов, требующих ортопедического лечения у лиц молодого возраста / В.А. Лабунец, Т.В. Диева, О.В. Лабунец/ Одеський медичний журнал. - 2012. - №4 (132). - c.4750 .

5. Лабунець О.В. Клінічне обгрунтування раннього ортопедичного лікування малих включених дефектів зубних рядів у молодому віці: Автореф. дис. на здоб. наук. ступеня канд. мед. наук: спец. 14.01.22 “Стоматологія”// О.В. Лабунець. - Одеса. - 2015. - 20 с.

6. Драгомирецкая М.С. Стоматологический статус молодежи Украины / М.С. Драгомирецкая, Т.В. Колесник, В.В. Лепский // Український стоматологічний альманах (матеріали наук. практ. конф. 3 міжнародною участю. Сучасні питання ортодонтії серед стоматологічних спеціальностей. Полтава 13-13 квітня 2012 р.: тези доп.). 2012. - Т:1, №2. - c.54-56.

7. Хоменко Л.А. Заболевания пародонта у лиц молодого возраста: проблема, риски и диагностика / Л.А. Хоменко, Н.В. Биденко, Е.И. Остапко // Стоматолог. - 2006. - №12. - c.54-58.

8. Косоверов Ю.Е. Уровень стоматологической заболеваемости и структура заболеваний пародонта у лиц молодого возраста // Весник стоматологии. - 2002. - №3. - с.45.

9. Кулыгина В.Н. Результаты исследования распространённости и структуры заболеваний пародонта у лиц молодого возраста // Український стоматологічний альманах. -
2013. - №5. - C. 29-31.

10. Камалов Р.Х. Частота уражень твердих тканин зубів і захворювань пародонту у молодого покоління Зброєних Сил України. - 2001. - №2. - Т.1. - С.148-152.

11. Камалов P.Х. Стан стоматологічного забезпечення військовослужбовців Зброєних Сил України та завдання 3 подальшого удосконалення стоматологічної допомоги в умовах недостатнього фінансування / Збір керівного складу медичної служби Зброєних Сил України 25-27 лютого 2004 р.: 3 доп. - К.:УВМА, 2004. - ч.II. - С.39-53.

12. Крячко А.Г. Стоматологічна захворюваність військовослужбовців України та розробка профілактичних заходів: автореф. дис. на здобуття наук. ступеню канд. мед. наук за спец.: 14.06.21 «Стоматологія»// А.Г. Крячко. - Одеca. $-2009 .-23 \mathrm{c}$.

13. Косенко К.Н. Стоматологическая заболеваемость призывников Военно-морских сил Украины / К.Н. Косенко, А.Г. Крячко // Вісник стоматології. - 2008. - №2. - С.112118.

14. Крячко А.Г. Стан здоров'я ротової порожнини у військовослужбовців військово-морських сил України / А.Г. Крячко // Військова медицина України. - 2007. - Том 7. №1. - c.23-25.

15. Стоматологическое обследование: Основные методы. - Женева, ВОЗ, 1989. - 62 с.

16. Эпидемиология, этиология и профилактика болезней пародонта // Доклад научной группы ВОЗ. Женева, 1980. -66 c.

\section{REFERENCES}

1. Muntjan L.M., Jur A.M. The incidence of, Prevalence of secondary partial adentia and dentofacial deformities in young patients. Ukrai'ns'kyj stomatologichnyj al'manah. 2010;5:25-26.

2. Ozhogan Z.R., Vdovenko L.P. Features of the clinical picture of dental defects in young people. Dental'ni tehnologii'. 2006;3-6(28-31):19-21.

3. Makjejev V.F., Martinek G.V. The frequency of defects of teeth and dentition in patients 13 to 17 years, depending on age. Ukrai'ns'kyj stomatologichnyj al'manah. 2012;4:106-110

4. Labunets V.A., Dieva T.V., Labunets O.V. Age related prevalence of dental row defects and crown defects requiring orthopedic treatment in young people. Odes'kyj medychnyj zhurnal. 2012;4(132):47-50.

5. Labunec' O.V. Klinichne obgruntuvannja rann'ogo ortopedychnogo likuvannja malyh vkljuchenyh defektiv zubnyh rjadiv u molodomu vici [Clinical justification of early orthopedic treatment of small included dental defects at a young age] Abstract of a candidate's thesis of medical sciences. Odesa. 2015:20.

6. Dragomiretskaya M.S., Kolesnik T.V., Lepskiy V.V. Dental status of young people in Ukraine. Ukraïns'kiy stomatologichniy al'manakh (materiali nauk. prakt. konf. z mizhnarodnoyu uchastyu. Suchasni pitannya ortodontii sered stomatologichnikh spetsial'nostey. Poltava 13-13 kvitnya 2012 r.: tezi dop.). 2012;2(1):54-56.

7. Khomenko L.A., Bidenko N.V., Ostapko E.I. Periodontal diseases in young people: the problem, risks and diagnosis. Stomatolog. 2006;1-2:54-58.

8. Kosoverov Yu.E. The level of dental morbidity and the structure of periodontal diseases in young people. Vestnik stomatologii. 2002;3:4-5.

9. Kulygina V.N. Results of research on the prevalence and structure of periodontal diseases in young people Ukrai'ns'kyj stomatologichnyj al'manah. 2013;5:29-31.

10. Kamalov R.H. Frequency of dental hard tissue lesions and periodontal diseases in the younger generation Zbrojenyh Syl Ukrai'ny. 2001;2(1):148-152. 
11. Kamalov R.H. The state of dental support for military personnel of the Armed Forces of Ukraine and the tasks for further improvement of dental care in conditions of insufficient funding. Zbir kerivnogo skladu medychnoi' sluzhby Zbrojenyh Syl Ukrai'ny 25-27 ljutogo 2004 r.: Z dop. - K.:UVMA, 2004;II:39-53.

12. Krjachko A.G. Stomatologichna zahvorjuvanist vijs'kovosluzhbovciv Ukrai'ny ta rozrobka profilaktychnyh zahodiv [Dental morbidity of Ukrainian military personnel and development of preventive measures]: Abstract of a candidate's thesis of medical sciences. Odesa;2009:23.

13. Kosenko K.N., Kryachko A.G. Dental morbidity of conscripts of the Ukrainian Navy. Visnyk stomatologii'. 2008;2:112-118.

14. Kryachko A.G. The state of oral health in military personnel of the Ukrainian Navy. Vijs'kova medycyna Ukrai'ny. 2007;1(7):23-25.

15. Stomatologicheskoe obsledovanie: Osnovnye metody. [Dental examination: Basic methods] Zheneva, VOZ;1989:62.

16. Epidemiologiya, etiologiya $i$ profilaktika bolezney parodonta [Epidemiology, etiology and prevention of periodontal diseases] Doklad nauchnoy gruppy VOZ. Zheneva; 1980:66.

Надійшла 27.05.2020

DOI 10.35220/2078-8916-2020-35-2-

УДК: 616.314-089.23-74:615.463

\section{O.V. Mytchenok, phd, N.V. Tabachniuk, phd, M.P. Mytchenok, phd}

Higher State Educational Establishment of Ukraine «Bukovinian State Medical University»

\section{COMPARATIVE ANALYSIS OF CEMENT PROPERTIES FOR FIXING VENEERS}

\section{ABSTRACT}

The natural beauty of teeth makes certain demands on dental materials and treatment methods.

One of the most popular methods of treatment of dental fluorosis recently is orthopedic treatment - the use of veneers, which have significant advantages over other types of restoration. Veneers give the tooth the most natural aesthetic appearance and restore the crown of the tooth to its original strength. And also veneers are translucent, so you can achieve a natural appearance even with ultraviolet radiation.

Aim. We set the task - to study the physicomechanical properties of these blocks of cement, in particular, to determine the film thickness of each cement when fixing various orthopedic structures, including veneers.

Materials and methods. The laboratory study of the studied blocks of cement was carried out in accordance with the recommendations of the international ISO standard. All samples were fabricated at $t 23+10 \mathrm{C}$ and relative humidity $50+10 \%$.

Cement mixing was carried out strictly according to the manufacturer's instructions. The quality of each cement was evaluated by film thickness and cement adhesion (tooth-construction).

Conclusions. To fix the veneers used for the treatment of cosmetic treatment and tooth fluorosis, the following blocks of cement were selected: RelyXTM ARC from $3 M$ ESPE, Bifix DC from Voco, Cemion.

The blocks of cement we studied in terms of film thicknesses of cement from different companies meet the requirements of the International Standard ISO and can be used for permanent fixation of veneers (RelyXTM ARC from $3 M$ ESPE, as well as prostheses of other designs (Bifix DC, Cemion).

Key words: teeth, cement, veneers.

\section{О.В. Митченок, Н.В. Табачнюк, М.П. Митченок}

Вищий державний навчальний заклад України «Буковинський державний медичний університет»

\section{ПОРІВНЯЛЬНИЙ АНАЛІЗ ВЛАСТИВОСТЕЙ ЦЕМЕНТІВ ДЛЯ ФІКСАЦІї ВІНІРІВ}

Природна краса зубів висуває певні вимоги до стоматологічних матеріалів і методів лікування.

Одним із найбільи популярних методів лікування флюорозу зубів $\epsilon$ ортопедичне лікування застосування вінірів, які мають істотні переваги перед іншими видами реставраиії. Вініри надають зубу найбільи природний естетичний вигляд $i$ повертають коронковій частині зуба початкову міцність. I щзе вініри - світлопроникні, завдяки чому можна добитися природності зовнішнього вигляду навіть при ультрафіолетовому випромінюванні.

Мета. Нами було поставлене завдання - дослідити фізико-механічні властивості иементів, зокрема визначити товщчину плівки кожного иементу при фіксації різних ортопедичних конструкцій, в тому числі і вінірів.

Матеріали та методи. Лабораторне вивчення досліджуваних нами иементів проводили відповідно до рекомендацій міжнародного стандарту ISO. Bci зразки були виготовлені при $t 23+10 C$ i відносній вологості 50+10\%. Замішування иементів проводили строго за інструкиією фірми виробника. Якість кожного цементу оцінювалося по товщині плівки $i$ адгезї иементу (зуб-конструкиія).

Висновки. Для фіксаиії вінірів, які застосовуються для лікування при косметичному дефекті і флюорозі зубів, були обрані иементи: RelyXTM ARC фірми 3M ESPE, Bifix DC фірми Vосо, иеміон. Досліджені нами иементи за показниками товщини плівки иементу різних фірм відповідають вимогам Міжнародного стандарту ISO $і$ можуть бути використані для постійної фіксачії вінірів (RelyXTM ARC фірми $3 M$ ESPE, так $і$ протезів інших конструкиій (Bifix DC, иеміон).

Ключові слова: зуби, цемент, вініри.

(C) Mytchenok O.V., Tabachniuk N.V., Mytchenok M.P., 2020. 